\title{
Microbial nitrogen transformations in unconsolidated coral reef sediments
}

\author{
Douglas G. Capone ${ }^{1, *}$, Susan E. Dunham², Sarah G. Horrigan², Linda E. Duguay ${ }^{1}$ \\ ${ }^{1}$ Chesapeake Biological Laboratory, Center for Environmental and Estuarine Studies, University of Maryland, Solomons, \\ Maryland 20688-0038, USA \\ ${ }^{2}$ Marine Sciences Research Center, State University of New York, Stony Brook, New York 11794-5000, USA
}

\begin{abstract}
Major nitrogen (N) pools and bacterial transformations of $\mathrm{N}$ were examined in carbonate sediments of 3 reefs in the central area of the Great Barrier Reef, Australia. Depth distributions of nitrate $\left(\mathrm{NO}_{3}{ }^{-}\right)$and ammonium $\left(\mathrm{NH}_{4}{ }^{+}\right)$and rates of $\mathrm{NH}_{4}{ }^{+}$production, $\mathrm{N}_{2}$ fixation (nitrogenase activity by $\mathrm{C}_{2} \mathrm{H}_{2}$ reduction) and denitrification were measured in muddy sediments of an inshore reef and in fine-, medium- and coarse-grained sediments at a midshelf and shelf edge reef. Ammonium efflux was estimated from pore water profiles. Estimates of potential rates of $\mathrm{NH}_{4}{ }^{+}$and $\mathrm{NO}_{3}{ }^{-}$utilization were made in the upper $2 \mathrm{~cm}$ of sediments at the midshelf and shelf edge reefs. Highest concentrations of $\mathrm{NH}_{4}{ }^{+}$(up to $70 \mu \mathrm{M}$ at $8 \mathrm{~cm}$ ) were observed in muddy carbonate sediments of inshore Pandora Reef, with somewhat lower concentrations (up to $20 \mu \mathrm{M}$ ) in fine-grained sands of the other 2 sites. Relatively small $\mathrm{NH}_{4}{ }^{+}$pools, usually less than $10 \mu \mathrm{M}$, typified coarse-grained sediments. Nitrate was generally undetectable in these sediments. Rates of $\mathrm{NH}_{4}^{+}$efflux among sites ranged from 0 to $4 \mu$ mol $\mathrm{N} \mathrm{m}^{-2} \mathrm{~h}^{-1}$, with highest fluxes associated with muds and fine-grained sands. Ammonification rates in the upper $2 \mathrm{~cm}$ ranged from 6 to $26 \mu \mathrm{mol} \mathrm{N} \mathrm{m} \mathrm{m}^{-2} \mathrm{~h}^{-1}$ among sites, generally increasing with depth. Nitrogenase activity was detected in all sediments examined, with highest rates near the surface. $\mathrm{N}_{2}$ fixation could account for more than $50 \%$ of $\mathrm{NH}_{4}{ }^{+}$production in the upper $2 \mathrm{~cm}$ of sediment at 3 of 4 sites. The potential in the upper $2 \mathrm{~cm}$ for $\mathrm{NH}_{4}{ }^{+}$consumption (nitrification and assimilation) ranged from 10 to $60 \mu \mathrm{mol} \mathrm{N} \mathrm{m} \mathrm{N}^{-2} \mathrm{~h}^{-1}$, while $\mathrm{NO}_{3}{ }^{-}$reduction potential ranged from 10 to $80 \mu \mathrm{mol} \mathrm{N} \mathrm{m}{ }^{-2} \mathrm{~h}^{-1}$ suggesting these may be quantitatively important pathways. Inhibitor experiments indicated that much of the $\mathrm{NH}_{4}^{+}$utilization might be by nitrification. Very high nitrification rates [up to $3.8 \mathrm{nmol} \mathrm{N}$ (g dry sed.) $)^{-1} \mathrm{~h}^{-1}$ or $70 \mu \mathrm{mol} \mathrm{N}$ $\mathrm{m}^{-2} \mathrm{~h}^{-1}$ ] were confirmed at 1 site by a ${ }^{15} \mathrm{~N}$ isotope dilution method. Low denitrification rates were also detected in these environments, and in many cases under apparently oxic conditions. However, highest rates noted were less than $5 \%$ of the rate of $\mathrm{NO}_{3}{ }^{-}$reduction. While shallow carbonate sands may be poor in organic material, they are active sites of bacterial $\mathrm{N}$ transformations. The $\mathrm{NH}_{4}{ }^{+}$and $\mathrm{NO}_{3}{ }^{-}$pools in the upper few $\mathrm{cm}$ appear to be highly dynamic, with estimated turnover times of substantially less than $1 \mathrm{~d}$. It is also noteworthy that bacterial $\mathrm{N}_{2}$ fixation appears to account for a much larger fraction of $\mathrm{NH}_{4}{ }^{+}$turnover than in shallow temperate zone sediments.
\end{abstract}

\section{INTRODUCTION}

Coral reefs are often likened to oases of biological productivity in a marine desert. The oligotrophic tropical waters which bathe reefs are often devoid of essential macronutrients (D'Elia 1988), and particularly nitrogen $(\mathrm{N})$ which is considered by many (but not all, e.g. Smith 1984) to be the primary limiting nutrient for these systems (D'Elia 1988). The apparent enigma of high biological productivity despite low inputs of $\mathrm{N}$ has been essentially solved by research over the last 2

\footnotetext{
- Addressee for correspondence
}

decades which has identified varied and intensive sites of biological $\mathrm{N}_{2}$ fixation on and around reefs (Capone 1983, 1988, D'Elia 1988, D'Elia \& Wiebe 1990).

Coral reefs are composed of consolidated areas of coral growth interspersed with areas of unconsolidated sediment containing coral and algal carbonate skeletons. Coral reef sediments have essentially been ignored until recently with regard to their importance in coral reef nutrient cycling, possibly because of their low organic content. Nonetheless, unconsolidated areas of reef sediment often greatly exceed the areal extent of the reef proper. Furthermore, the recent findings that $\mathrm{O}_{2}$ can be depleted within centimeters of the sediment surface (King et al. 1990) suggests that 
anaerobic biogeochemical processes are operative around the reef and may be important in the various nutrient cycles (DiSalvo 1973, Nedwell \& Blackburn 1987).

Microorganisms in the sediment are capable of various $N$ transformations which can affect the forms and concentration of $N$. Many of the microbial $N$ transformations, such as denitrification and ammonification, are predominantly anaerobic, and may therefore occur in the sediments.

We therefore concurrently examined the distribution of inorganic $\mathrm{N}$ species, sediment surface nitrification and the depth distribution of $\mathrm{N}_{2}$ fixation, ammonification, and denitrification in sediments of the Great Barrier Reef at 3 sites ranging from an oligotrophic outer shelf reef to a more eutrophic reef closer to shore.

\section{MATERIALS AND METHODS}

Study sites. Microbial $N$ transformations were investigated in shallow (1 to $25 \mathrm{~m}$ water depth) carbonate sediments di severd siles dung the central portion of the Great Barrier Reef, Australia (Fig. 1). Bowl Reef is located on the outer edge of the Great Barrier Reef. Hopkinson Reef is due west of Bowl, on the middle shelf. Pandora Reef is relatively close to the mainland in the inner reef track. Sampling location details for each site are given in Table 1. Sampling and experiments occurred during two 2 wk cruises aboard the RV 'Sirius' (Nov 1985) and RV 'Lady Basten' (Dec 1985) of the Australian Institute of Marine Sciences.

Sediment cores. Cores of up to the top $10 \mathrm{~cm}$ of sediment were manually collected by SCUBA or snor-

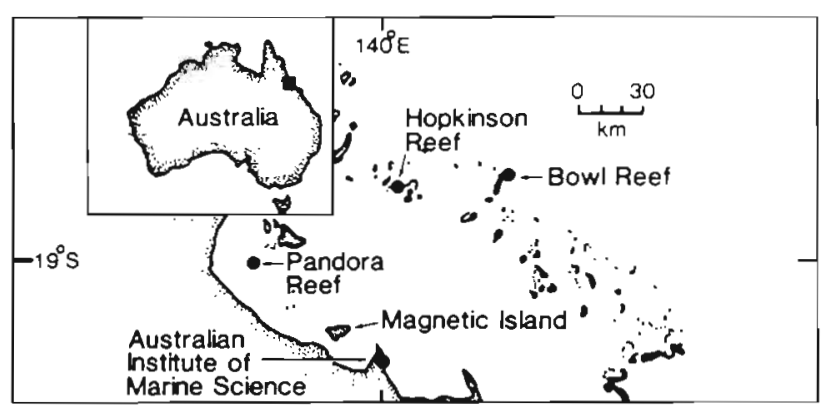

Fig. 1. Map of reef site locations

keling using plastic core tubes (diameter $3.5 \mathrm{~cm}$ ) or, for microbial assays, cut-off 30 or $50 \mathrm{cc}$ plastic syringes, $10 \mathrm{~cm}$ length $\times 2 \mathrm{~cm}$ or $2.6 \mathrm{~cm}$ diameter, respectively. Barrel cores were gently inserted into the sediments to minimize disturbance. Syringe cores were used as piston cores, with the plunger in place and slowly withdrawn as the core was inserted. For each, black rubber stoppers were used to seal core ends. Samples were returned to the shipboard laboratory and processed as sưon after sampling âs possible, usuaculy withiñ 2 h.

Pore water analysis. Sediments were analyzed for pore water $\mathrm{NH}_{4}{ }^{+}, \mathrm{NO}_{3}{ }^{-}$and $\mathrm{NO}_{2}^{-}$using standard (manual) seawater methods (Strickland \& Parsons 1972). Pore waters were collected by 2 methods. Cores returned to shipboard were segmented in $2 \mathrm{~cm}$ increments and the pore waters collected by vacuum filtration in a Hoefer 10-position vacuum filtration manifold. Alternately, in coarse- or medium-grained sediments, we used a modified teflon 'sipper' with low dead volume with a $1 \mathrm{~cm}$ porous frit near the tip which was manually inserted into the sediment. At $2 \mathrm{~cm}$ intervals

Table 1 Site characteristics and interstitial ammonium concentrations; filt: filtered; sip; sipped

\begin{tabular}{|c|c|c|c|c|c|c|}
\hline \multirow[t]{2}{*}{ Site } & \multirow[t]{2}{*}{$\begin{array}{l}\text { Depth } \\
\text { (m) }\end{array}$} & \multirow[t]{2}{*}{$\begin{array}{l}\text { Sediment } \\
\text { type }\end{array}$} & \multirow[t]{2}{*}{ Location } & \multirow[t]{2}{*}{ Date/method } & \multicolumn{2}{|c|}{$\begin{array}{c}\mathrm{NH}_{4}{ }^{+} \text {concentration } \\
(\mu \mathrm{M})\end{array}$} \\
\hline & & & & & $0-2 \mathrm{~cm}$ & $6-8 \mathrm{~cm}$ \\
\hline Pandora & 10 & Mud & Forereef & $\begin{array}{l}11 \text { Nov/filt } \\
12 \text { Nov/filt }\end{array}$ & $\begin{array}{r}15.0 \\
6.1\end{array}$ & $\begin{array}{l}67.0 \\
57.0\end{array}$ \\
\hline Hopkinson 1 & 10 & Fine sand & Backreef & $\begin{array}{l}5 \text { Nov/sip } \\
5 \text { Nov/filt } \\
6 \text { Nov/filt }\end{array}$ & $\begin{array}{r}0.8 \\
11.3 \\
1.5\end{array}$ & $\begin{array}{l}17.9 \\
11.6 \\
18.1\end{array}$ \\
\hline Hopkinson A & 20 & Fine sand & Backreef & 9 Nov/filt & 4.0 & 19.4 \\
\hline Hopkinson B & 10 & Medium sand & Backreef & 9 Nov/filt & 1.8 & 8.4 \\
\hline Hopkinson C & 2 & Coarse sand & Reef flat & $\begin{array}{l}20 \mathrm{Dec} / \mathrm{filt} \\
20 \mathrm{Dec} / \mathrm{sip}\end{array}$ & $\begin{array}{l}6.6 \\
2.9\end{array}$ & $\begin{array}{r}23.5 \\
7.6\end{array}$ \\
\hline Hopkinson D & 20 & Medium sand & Forereef & 8 Nov/sip & 5.3 & 5.9 \\
\hline Bowl A & 10 & Medium sand & Backreef & $\begin{array}{l}13 \mathrm{Dec} / \mathrm{sip} \\
14 \mathrm{Dec} / \mathrm{filt}\end{array}$ & $\begin{array}{r}2.4 \\
19.2\end{array}$ & $\begin{array}{l}17.6 \\
29.8\end{array}$ \\
\hline Bowl B & 20 & Fine sand & Backreef & $12 \mathrm{Dec} / \mathrm{sip}$ & 2.6 & 8.4 \\
\hline Bowl C & 10 & Coarse sand & Backreef & $11 \mathrm{Dec} / \mathrm{sip}$ & 1.2 & 1.2 \\
\hline
\end{tabular}


down to about $10 \mathrm{~cm}$, ca $10 \mathrm{ml}$ was withdrawn by plastic syringe and returned to the surface for analysis.

Solid phase analysis. Known volumes of sediment in $2 \mathrm{~cm}$ intervals were dried at $105^{\circ} \mathrm{C}$. The weight loss per volume was used to estimate sediment porosity (Berner 1980). Dried sediments were analyzed for total CN on a Leco CHN600 and, after dissolution of carbonates, for organic carbon (Sandstrom et al. 1986).

Ammonium fluxes. Diffusive $\mathrm{NH}_{4}{ }^{+}$fluxes were computed (Berner 1980) for sites with an $\mathrm{NH}_{4}{ }^{+}$gradient in the upper sediment column, using a molecular diffusion coefficient (D) of $19.8 \times 10^{-6} \mathrm{~cm}^{2} \mathrm{~s}^{-1}$ (Li \& Gregory 1972, Krom \& Berner 1980) corrected for tortuosity using the measured porosity and assuming a formation factor $(F)$ of 2.228 for the calculation of the sediment diffusion coefficient $\left(D_{s}\right)$. No correction was made for adsorption (Rosenfeld 1979).

Ammonification. For the depth profiles of $\mathrm{NH}_{4}{ }^{+}$production in carbonate sands, triplicate samples were collected in $60 \mathrm{cc}$ Plastipak syringes with plungers in place but from which the end had been removed to allow for coring. Cores were taken to a depth of at least. $8 \mathrm{~cm}$. The open ends were capped in the field with a \#6 black rubber stopper. Upon return to the ship, the plunger was carefully removed by breaking the seal with a needle. Approximately $10 \mathrm{ml}$ of ambient seawater was gently added to provide an overlying water phase. The plungers were then carefully replaced on all cores and kept sealed until harvested. Cores were sampled at zero time and at various time intervals to establish the rate of $\mathrm{NH}_{4}{ }^{+}$production. At sampling times, the plunger was gently removed by breaking the seal with a needle. Overlying water was removed by syringe, and the samples were filtered through Whatman $\mathrm{GF} / \mathrm{C}$ filters and refrigerated until analyzed for $\mathrm{NH}_{4}{ }^{+}$.

The plunger was then replaced and used to extrude and section the core from the bottom up, in 8 to 6,6 to 4 , 4 to 2 , and 2 to $0 \mathrm{~cm}$ segments. Each segment was placed in a filtration tower of a Hoefer filtration apparatus, and the pore waters were passed through $\mathrm{GF} / \mathrm{C}$ filters into scintillation vials in the manifold. For the initial samples (e.g. zero time and 6 h), replicates for each horizon had to be combined to obtain sufficient volume (2 to $3 \mathrm{ml}$ ) for analysis. At subsequent time points, individual replicates could be analyzed separately since they required dilution.

Acetylene reduction and acetylene blockage assays. Nitrogenase activity was measured on both cruises using the acetylene reduction assay (Stewart et al. 1967, Hardy et al. 1968) as adapted for marine sediments (Capone 1982, O'Neil \& Capone 1989). Because of instrument problems, denitrification was estimated only on the second cruise by the acetylene blockage method (Payne 1984, Slater \& Capone 1987).
Acetylene $\left(\mathrm{C}_{2} \mathrm{H}_{2}\right)$, generated from calcium carbide, was added to the experimental flasks to a final volume equal to $20 \%$ of the gas head space volume (vol:vol). Flasks were incubated in the dark and experiments were carried out within $2^{\circ} \mathrm{C}$ of ambient temperature (25 to $30^{\circ} \mathrm{C}$ ). Control experiments with sediment and no additions of $\mathrm{C}_{2} \mathrm{H}_{2}$, as well as flasks containing filtered seawater alone with additions of $\mathrm{C}_{2} \mathrm{H}_{2}$, were also conducted.

In general, samples of the top $4 \mathrm{~cm}$ of sediment from $30 \mathrm{cc}$ syringe cores were extruded directly into $175 \mathrm{ml}$ wide mouth Erlenmeyer flasks which were then sealed with black rubber stoppers. Alternately, for depth profiles, $2 \mathrm{~cm}$ increments were extruded into flasks. For most experiments, samples were not slurried by addition of seawater. For anaerobic experiments, stoppered flasks were gassed with $\mathrm{N}_{2}$ for 2 to 3 min through incurrent and excurrent hypodermic needles inserted through the stopper. Flask headspace was occasionally sampled and checked for $\mathrm{O}_{2}$ concentrations using electron capture gas chromatography.

Gas samples $(100 \mu l)$ were withdrawn from the headspace of the experimental flasks with a gas tight syringe and analyzed immediately for ethylene $\left(\mathrm{C}_{2} \mathrm{H}_{4}\right)$ production using flame ionization or nitrous oxide $\left(\mathrm{N}_{2} \mathrm{O}\right)$ by electron capture detection on a Shimadzu Mini 2 gas chromatograph. Gases were separated on $2 \mathrm{~m} \times 3 \mathrm{~mm}$ Porapak R columns, held at $70^{\circ} \mathrm{C}$. Injector temperature $=150^{\circ} \mathrm{C}_{;} \mathrm{N}_{2}$ carrier flow $=\mathrm{ca} 30 \mathrm{ml} \mathrm{min}^{-1}$; $\mathrm{H}_{2}=\mathrm{ca} 30 \mathrm{ml} \mathrm{min}{ }^{-1} ;$ air flow $=\mathrm{ca} 300 \mathrm{ml} \mathrm{min}^{-1}$.

Peak heights of $\mathrm{C}_{2} \mathrm{H}_{4}$ or $\mathrm{N}_{2} \mathrm{O}$ were measured on a Hewlett-Packard 3390A integrator and converted to nmol of gas by comparison to peaks of $\mathrm{C}_{2} \mathrm{H}_{4}$ or $\mathrm{N}_{2} \mathrm{O}$ standards of known concentrations. Sediment samples were dried to constant weight at 60 to $100^{\circ} \mathrm{C}$, and rates of $\mathrm{C}_{2} \mathrm{H}_{4}$ or $\mathrm{N}_{2} \mathrm{O}$ production were normalized to dry weight of sediment. Rates of $\mathrm{C}_{2} \mathrm{H}_{2}$ reduction or $\mathrm{N}_{2} \mathrm{O}$ production as nmol (dry wt sed.) ${ }^{-1} \mathrm{~h}^{-1}$ were determined by performing linear regression analysis to determine the average slope of replicates for each parameter over the initial 12 to $24 \mathrm{~h}$ of incubation.

Ammonium utilization, nitrification and nitrate reduction. The potentials for $\mathrm{NH}_{4}{ }^{+}$utilization and $\mathrm{NO}_{3}{ }^{-}$reduction in the upper $2 \mathrm{~cm}$ were assessed in aerobic slurry incubations with defined $\mathrm{NO}_{3}{ }^{-}$and $\mathrm{NH}_{4}{ }^{+}$concentrations by noting changes in these pools over $24 \mathrm{~h}$ periods. On 2 occasions, nitrification rate was determined using the ${ }^{15} \mathrm{~N}-\mathrm{NO}_{3}{ }^{-}$isotope dilution method (Koike \& Hattori 1978, Horrigan \& Capone 1985). The top $2 \mathrm{~cm}$ from seven $50 \mathrm{cc}$ syringe cores were combined and sieved through a $2 \mathrm{~mm}$ mesh. For each experiment, $5 \mathrm{cc}$ portions of sediment were dispensed into six $125 \mathrm{ml}$ Erlenmeyer flasks. Experiments were initiated by addition of $50 \mathrm{ml}$ of a $10 \mu \mathrm{M} \mathrm{NO}_{3}{ }^{-}$las ${ }^{15} \mathrm{NO}_{3}{ }^{-}$) and $10 \mu \mathrm{M} \mathrm{NH}{ }_{4}{ }^{+}$solution. Flasks were placed 
in a water bath in the dark for incubation. Two flasks were harvested at 0,24 and $48 \mathrm{~h}$. For harvesting, the contents of the flask were filtered onto a $4.25 \mathrm{~cm}$ Whatman GF/C filter previously rinsed with distilled water. After filtering, the sediment was collected and placed in a tared scintillation vial for dry weight analysis. The filtrate was collected, with about $20 \mathrm{ml}$ used for nutrient analysis. For ${ }^{15} \mathrm{~N}$ experiments, the remainder was frozen for subsequent solvent extraction of $\mathrm{NO}_{3}{ }^{-}$and determination of ${ }^{15} \mathrm{~N}:{ }^{14} \mathrm{~N}$ isotopic ratio by mass spectrometry (Horrigan \& Capone 1985).

On one occasion (22 Dec, Hop C), parallel experiments also examined the use of chlorate (Belser \& Mays 1982) and N-Serve (Webb \& Wiebe 1975) as specific inhibitors of nitrification. Chlorate was added to a final concentration of $10 \mathrm{mM}$, while $\mathrm{N}$-Serve dissolved in DMSO was added to a final concentration of $10 \mathrm{ppm}$ (wt/vol). From these flasks, $10 \mathrm{ml}$ subsamples of the liquid phase were removed over the time course of the experiment for inorganic $\mathrm{N}$ analysis.

\section{RESULTS}

\section{Site characteristics}

Among the 3 sites, highest $\mathrm{NH}_{4}{ }^{+}$levels in bottom waters were found at Pandora Reef (Table 2). Bottom water $\mathrm{NH}_{4}{ }^{+}$levels were lower at Bowl and Hopkinson Reefs (Table 2). Bottom $\mathrm{NO}_{3}{ }^{-}$levels at Pandora Reef were also greater than either Bowl or Hopkinson Reefs.

Ammonium concentrations in the upper $10 \mathrm{~cm}$ of sediments from Bowl and Hopkinson Reefs were generally similar for comparable sediment types. For finegrained sediments, $\mathrm{NH}_{4}{ }^{+}$concentrations increased rapidly over the upper few $\mathrm{cm}$, leveling off at 10 to $30 \mu \mathrm{M}$ by $7 \mathrm{~cm}$ (Fig. 2A, Table 1). Ammonium concentrations in coarse-grained sands were generally much lower, usually less than $10 \mu \mathrm{M}$ by $10 \mathrm{~cm}$ depth (Fig. 2B). An exception to this was the reef flat sediment at Hopkinson Reef (Hop C; Fig. 2B) which had an increase in $\mathrm{NH}_{4}{ }^{+}$with depth more typical of the finer grained sands. Fine muds were sampled only at Pandora Reef, and these sediments had the sharpest gra-

Table 2. Bottom water ammonium and nitrate concentrations; means $\pm S E$, with number of replicates in parentheses

\begin{tabular}{|lccc|}
\hline Station/Month & $\begin{array}{c}\text { Ammonium } \\
(\mu \mathrm{M})\end{array}$ & \multicolumn{2}{c|}{$\begin{array}{c}\text { Nitrate } \\
(\mu \mathrm{M})\end{array}$} \\
\hline Hopkinson/Nov & $0.67 \pm 0.30(6)$ & $0.70 \pm 0.21 \quad(5)$ \\
Hopkinson/Dec & $0.61 \pm 0.23(7)$ & $0.27 \pm 0.03 \quad(7)$ \\
Pandora/Nov & $1.61 \pm 0.68(10)$ & $1.18 \pm 0.25(10)$ \\
Bowl/Dec & $0.55 \pm 0.55(11)$ & $0.59 \pm 0.17 \quad(7)$ \\
\hline
\end{tabular}

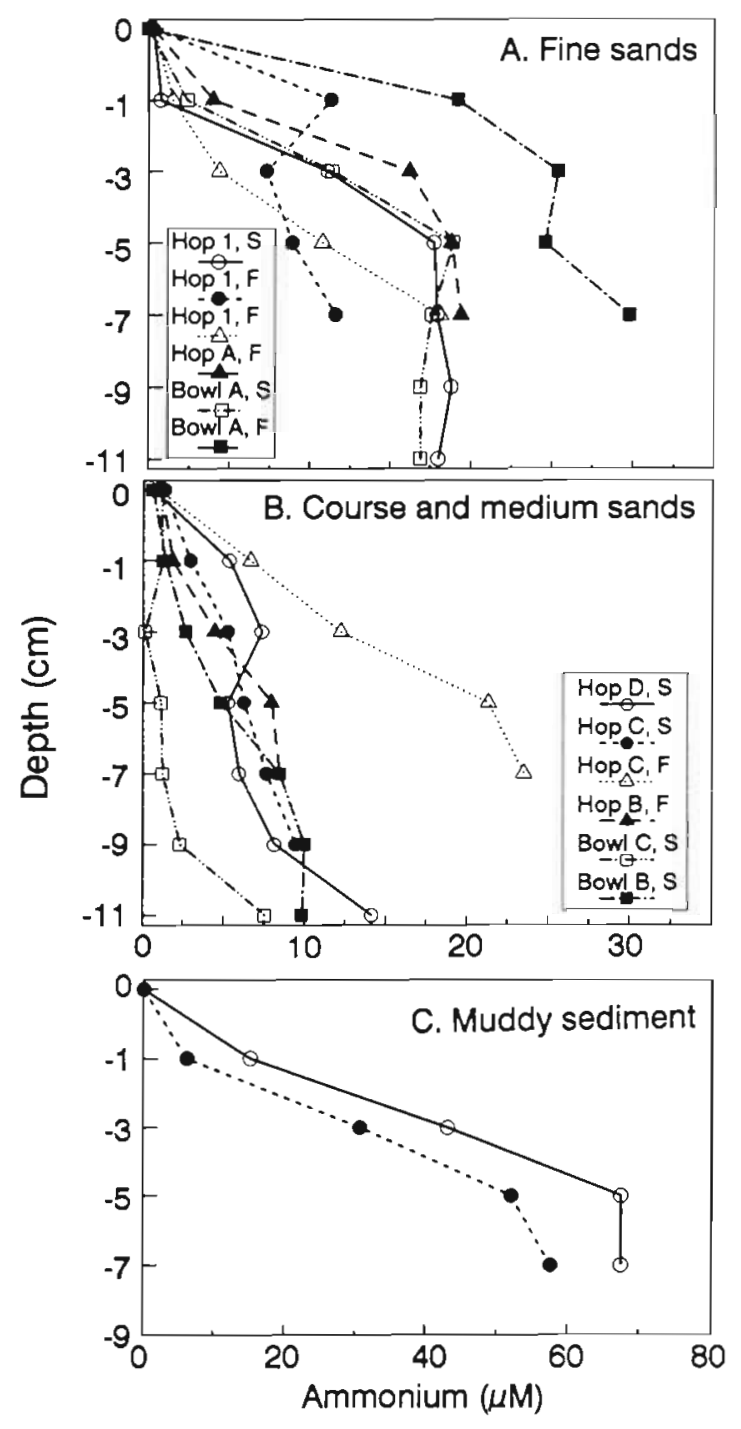

Fig. 2. Depth distributions of ammonium in (A) fine, (B) medium and coarse and (C) muddy carbonate sediments. See Table 1 for more detail on site designation and characterization. Hop: Hopkinson; S: sippers; F: filtered

dients and highest concentrations (Fig. 2C, Table 1). The lowest $\mathrm{NH}_{4}{ }^{+}$concentrations were noted in sediments from Bowl Reef (Bowl C; Fig. 2B), a station which we observed to be densely populated with Callianassa shrimp.

With respect to the 2 procedures used for collecting pore waters, sipper values (S) were generally lower than values derived by vacuum filtration of sediment segments $(F)$, particularly for the shallowest horizons $(0$ to $2 \mathrm{~cm}$ ). Closer agreement between the 2 sampling protocols occurred for fine sands at deeper horizons (e.g. Hop 1 and Bowl $A_{i}$ Table 1). Sippers were incapable of obtaining samples in the muddy sediments of Pandora Reef. Subsequent analyses were restricted to data from filtration-derived samples. 
Table 3. Solid phase analysis of study sites. Where indicated, values are means of triplicate determination ( $\pm \mathrm{SE}$ )

\begin{tabular}{|c|c|c|c|}
\hline $\begin{array}{l}\text { Particulate } N \\
\text { (\% dry wt) }\end{array}$ & $\begin{array}{l}\text { Organic C } \\
\text { (\% dry wt) }\end{array}$ & $\mathrm{C} / \mathrm{N}$ & Porosity \\
\hline \multicolumn{4}{|l|}{ Pandora Reef (mud) } \\
\hline $0-2 \quad 0.170 \pm 0$ & $0.550 \pm 0.060$ & 3.2 & 0.708 \\
\hline $6-8 \quad 0.140$ & 0.530 & 3.8 & 0.709 \\
\hline $0-8 \quad 0.145$ & 0.538 & 3.7 & 0.707 \\
\hline \multicolumn{4}{|c|}{ Hopkinson Reef A (fine-grained) } \\
\hline $0-2 \quad 0.083 \pm 0.007$ & $0.233 \pm 0.003$ & 2.8 & $0.526 \pm 0.009$ \\
\hline 0.050 & 0.270 & 5.4 & $0.506 \pm 0.008$ \\
\hline $0-8 \quad 0.064$ & 0.232 & 3.6 & 0.506 \\
\hline \multicolumn{4}{|c|}{ Hopkinson Reef B (medium-grained) } \\
\hline $0-2 \quad 0.133 \pm 0.013$ & $0.240 \pm 0.006$ & 1.8 & $0.496 \pm 0.006$ \\
\hline $6-8 \quad 0.070$ & 0.190 & 2.7 & $0.476 \pm 0.001$ \\
\hline $0-8 \quad 0.094$ & 0.215 & 2.3 & 0.479 \\
\hline \multicolumn{4}{|c|}{ Hopkinson Reef $\mathrm{C}$ (coarse-grained) } \\
\hline $0-2 \quad 0.067 \pm 0.009$ & $0.263 \pm 0.007$ & 4.0 & $0.560 \pm 0.007$ \\
\hline $6-8 \quad 0.043 \pm 0.020$ & $0.243 \pm 0.035$ & 5.6 & $0.512 \pm 0.002$ \\
\hline 0.054 & 0.242 & 4.5 & 0.534 \\
\hline
\end{tabular}

Bulk phase analyses were performed on sediments from several of the sites (Table 3). Particulate $N$ was highest in the muddy Pandora Reef sediment, and lowest in the coarse-grained sands. The muddy sediment had about twice the organic $C$ content of the sands (Table 3). Porosities were also highest in the muddy sediments, compared to the sands. Sediment diffusion coefficients $\left(D_{\mathrm{s}} \times 10^{6} \mathrm{~cm}^{2} \mathrm{~s}^{-1}\right)$ calculated for several of the sites were 12.6 (Pandora, mud), 16.9 (Hop B, fine), 17.9 (Hop A, medium) and 15.9 (Hop C, coarse).

\section{Ammonification}

Ammonium production in intact cores was examined at several of the stations (Fig. 3; Table 4). At Pandora Reef, $\mathrm{NH}_{4}{ }^{+}$production rates were relatively constant with depth, ca $0.25 \mathrm{nmol}$ (g dry sed.) $)^{-1} \mathrm{~h}^{-1}$. Similarly, at

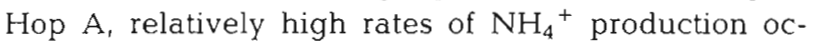
curred through the upper $8 \mathrm{~cm}$, with the lowest rates in the upper $2 \mathrm{~cm}$. At Hop B, while little ammonification was noted in the upper $4 \mathrm{~cm}$, high rates of $\mathrm{NH}_{4}{ }^{+}$ production occurred below $4 \mathrm{~cm}$. In contrast, at 2 sites with medium-grained sands, substantial $\mathrm{NH}_{4}{ }^{+}$production was found only in the upper $2 \mathrm{~cm}$. At shallow, coarse-grained Hop C, $\mathrm{NH}_{4}{ }^{+}$production, while highest at the surface, was substantial down to the deepest horizon sampled (6 to $8 \mathrm{~cm}$ ) (Fig. 3).

\section{Ammonium and nitrate utilization}

Net changes in $\mathrm{NH}_{4}{ }^{+}$and $\mathrm{NO}_{3}{ }^{-}$pools were also examined over $24 \mathrm{~h}$ periods in aerobic sediment slur-

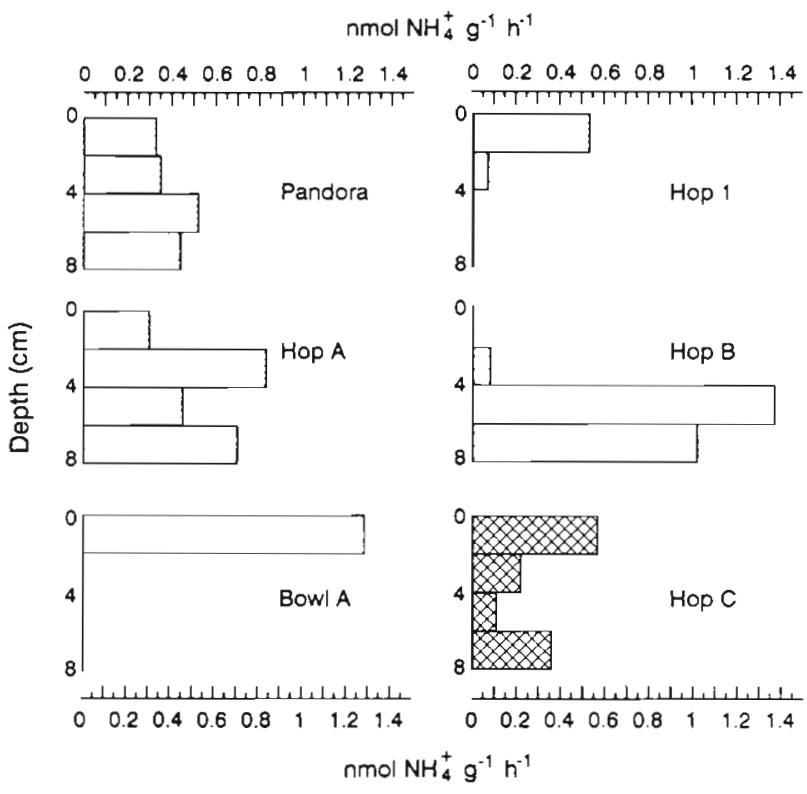

Fig. 3. Depth distributions of ammonium production at several sites. Fine stipple indicate muds and fine-grained sediments, medium stipple are medium-grained and cross hatch are coarse-grained

ries of the upper $2 \mathrm{~cm}$ from several of the sites (Table 4 ). Relatively high potential rates of $\mathrm{NH}_{4}{ }^{+}$utilization, either through nitrification or assimilation, occurred in all cases examined. Values ranged from 0.54 to 2.9 nmol (g dry sed.) ${ }^{-1} \mathrm{~h}^{-1}$. Similarly, most sites also had appreciable rates of $\mathrm{NO}_{3}{ }^{-}$removal, ranging from 0.5 to $1.8 \mathrm{nmol}$ (g dry sed.) ${ }^{-1} \mathrm{~h}^{-1}$. Medium-grained Hop B had lowest rates of both $\mathrm{NH}_{4}{ }^{+}$and $\mathrm{NO}_{3}{ }^{-}$consumption while fine-grained Hop 1 had highest rates of each (Table 4). In the coarse-grained reef flat sediments of Hop C, very 
Table 4. Rates of net ammonium production, net ammonium and nitrate utilization, denitrification and nitrogen fixation. Nitrogen fixation data previously reported in O'Neil \& Capone (1989). Where indicated, data are means \pm SE with number of replicates in parentheses. Hop: Hopkinson; nd: not determined

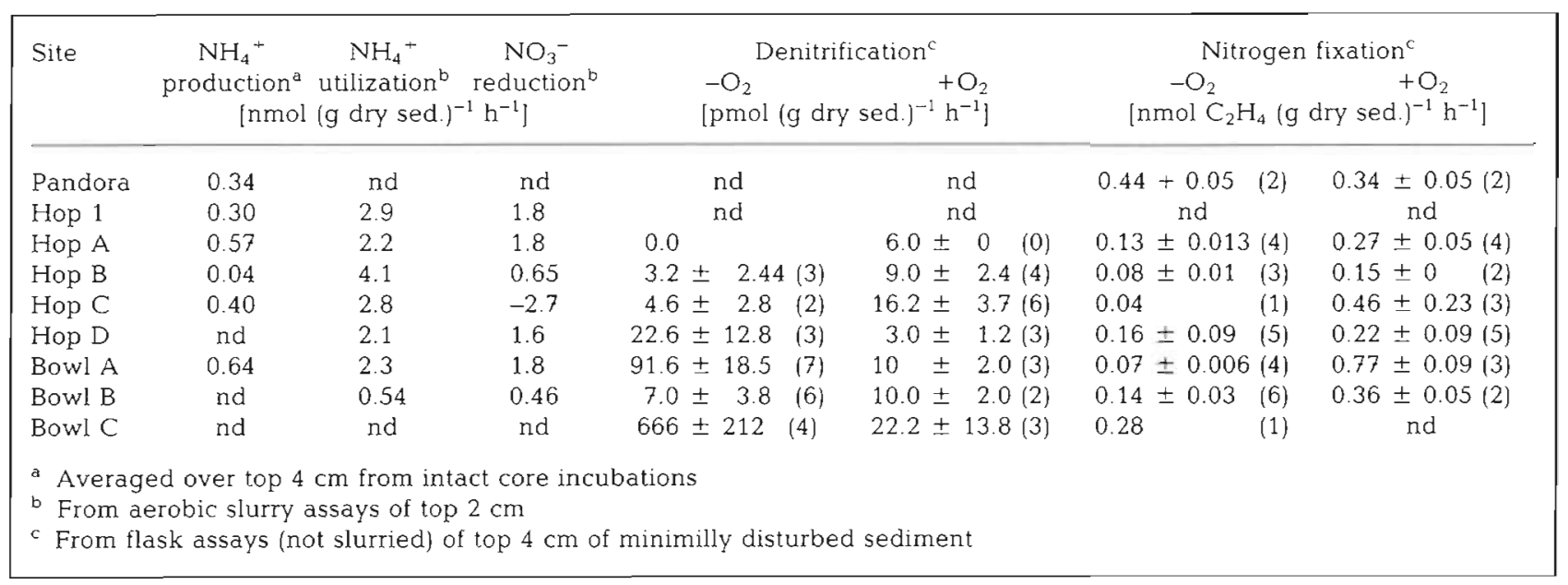

high rates of net $\mathrm{NO}_{3}{ }^{-}$production, rather than removal, occurred (Table 4).

\section{Nitrification}

For Hop C, the only site which exhibited net rates of $\mathrm{NO}_{3}{ }^{-}$production, nitrification was examined by several methods on 2 dates (Table 5). On $18 \mathrm{Dec}$, total nitrifica-

Table 5. Comparison of nitrification estimates in coral reef sediments by several methods at Stn Hopkinson C

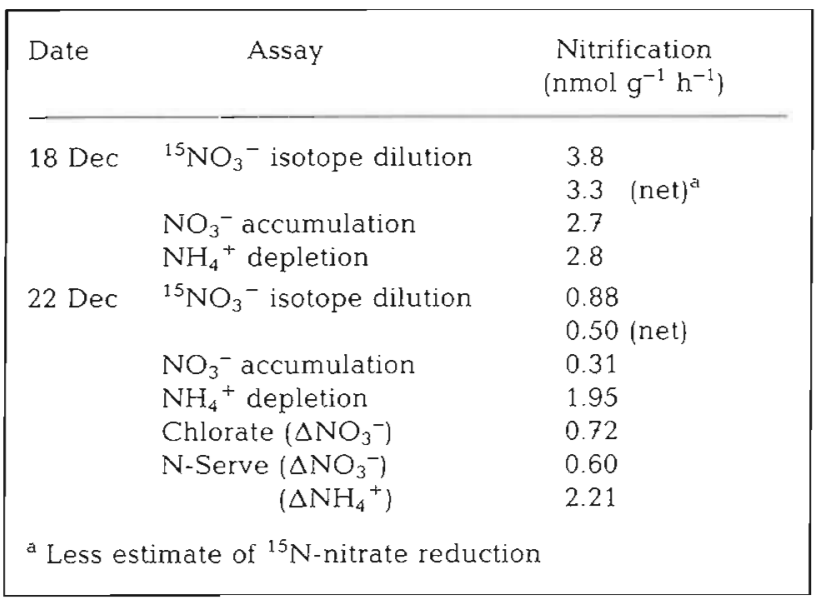

tion rates based on ${ }^{15} \mathrm{NO}_{3}{ }^{-}$isotope dilution were about 7.6 fold greater than concurrent $\mathrm{NO}_{3}{ }^{-}$reduction rates [3.8 vs $0.5 \mathrm{nmol}$ (g dry sed.) ${ }^{-1} \mathrm{~h}^{-1}$ ], based on ${ }^{15} \mathrm{~N}$. Net $\mathrm{NH}_{4}{ }^{+}$depletion and $\mathrm{NO}_{3}{ }^{-}$accumulation rates were about $74 \%$ and $71 \%$ of the total nitrification rate, respectively, and $85 \%$ and $82 \%$ of the net nitrification rate.

On $22 \mathrm{Dec},{ }^{15} \mathrm{~N}$-nitrification rates were only $23 \%$ of the rate on the previous sampling. Total nitrification was about 2.3 times the concurrent ${ }^{15} \mathrm{~N}-\mathrm{NO}_{3}{ }^{-}$reduction rate $\left[0.88\right.$ vs $0.38 \mathrm{nmol} N$ (g dry sed.) $\left.{ }^{-1} \mathrm{~h}^{-1}\right]$. The ${ }^{15} \mathrm{~N}$ based estimate was 2.8 times the $\mathrm{NO}_{3}{ }^{-}$accumulation rate and $45 \%$ of the net $\mathrm{NH}_{4}{ }^{+}$accumulation rate. Inhibitor assays of nitrification using chlorate, performed on $22 \mathrm{Dec}$, did not detect any $\mathrm{NO}_{2}{ }^{-}$accumulation; however, they did result in $\mathrm{NO}_{3}{ }^{-}$consumption, compared to accumulation in controls and thus yielded an estimate of nitrification about $82 \%$ of the gross rate of nitrification based on the ${ }^{15} \mathrm{~N}$ method. Similarly, assays using $\mathrm{N}$-Serve resulted in production of $\mathrm{NH}_{4}{ }^{+}$ and depletion of $\mathrm{NO}_{3}{ }^{-}$and yielded estimates of nitrification of $68 \%$ (based on decrease in $\mathrm{NO}_{3}{ }^{-}$production rate) and $251 \%$ (based on decrease in $\mathrm{NH}_{4}{ }^{+}$consumption rate) of the ${ }^{15} \mathrm{~N}$-based estimate (Table 5).

\section{Denitrification}

Low denitrification rates occurred in most of the sediments examined (Table 4). Highest rates were found in medium- and coarse-grained sediments from Bowl Reef incubated under anaerobic conditions. Consistently higher denitrification rates were noted in aerobically, compared to anaerobically, incubated sediments from 2 of the sites at Hopkinson Reef (Hop C: Table 4). Depth profiles performed at Bowl A found similar rates of activity down to $8 \mathrm{~cm}$ while a depth profile at Hop $\mathrm{C}$ detected denitrification only in the upper $4 \mathrm{~cm}$ (data not shown). 
Table 6. Areal rates of ammonification and nitrogen fixation in reef sediments. $\mathrm{NH}_{4}^{+}$turnover calculated from the $\mathrm{NH}_{4}{ }^{+}$ production rate $/ \mathrm{NH}_{4}{ }^{+}$inventory (from $\Upsilon$ able 2 ) for the indicated depth interval. nd: not determined

\begin{tabular}{|c|c|c|c|c|c|c|c|c|}
\hline \multirow{3}{*}{$\begin{array}{l}\text { Site } \\
\text { Pandora }\end{array}$} & \multicolumn{2}{|c|}{$\mathrm{NH}_{4}^{+}$production } & \multicolumn{2}{|c|}{$N_{2}$ fixation } & \multicolumn{2}{|c|}{$\mathrm{N}_{2}$ fix $/ \mathrm{NH}_{4}$ prod } & \multicolumn{2}{|c|}{$\mathrm{NH}_{4}{ }^{+}$turnover } \\
\hline & $0-2 \mathrm{~cm}$ & $\begin{array}{l}0-8 \mathrm{~cm} \\
\left(\mu \mathrm{mol} \mathrm{NH} H_{4}+\right.\end{array}$ & $\begin{array}{c}0-2 \mathrm{~cm} \\
\left.\mathrm{~m}^{-2} \mathrm{~h}^{-1}\right)\end{array}$ & $0-8 \mathrm{~cm}$ & $0-2 \mathrm{~cm}$ & $0-8 \mathrm{~cm}$ & $0-2 \mathrm{~cm}$ & $0-8 \mathrm{~cm}$ \\
\hline & 6.6 & 32.9 & 3.6 & 5.3 & 0.55 & 0.16 & 0.04 & 0.009 \\
\hline Hopkinson 1 & 10.6 & 12.0 & nd & nd & - & - & 0.15 & 0.022 \\
\hline Hopkinson A & 6.0 & 45.6 & 4.9 & 8.5 & 0.82 & 0.19 & 0.05 & 0.048 \\
\hline Hopkinson C & 11.4 & 25.2 & 8.2 & 12.9 & 0.72 & 0.51 & 0.15 & 0.037 \\
\hline Bowl A & 25.6 & 25.6 & 1.5 & 5.0 & 0.06 & 0.20 & 0.10 & 0.021 \\
\hline
\end{tabular}

\section{$\mathrm{N}_{2}$ fixation}

Nitrogenase activity was detected in all sediments examined (also reported in O'Neil \& Capone 1989). At all stations, activity was highest in the upper $2 \mathrm{~cm}$ (Fig. 4). For the fine- through coarse-grained sediments, nitrogenase activity in the upper few $\mathrm{cm}$ was
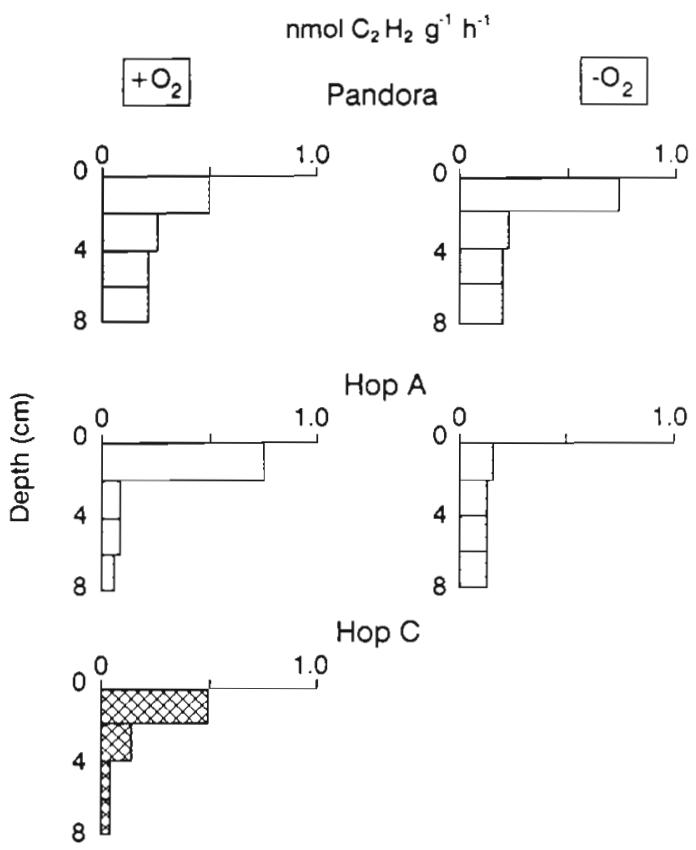

Fig. 4. Depth distribution of $\mathrm{C}_{2} \mathrm{H}_{2}$ reduction at several sites. Fine stipple are muddy sediments, medium stipple are finegrained whereas cross hatch are coarse-grained

generally higher under aerobic conditions. In Pandora Reef muds, nitrogenase activity in surficial sediments was somewhat higher under anaerobic conditions. Activities ranged from a high of about $0.77 \mathrm{nmol} \mathrm{C}_{2} \mathrm{H}_{2}$ (g dry sed.) $)^{-1} \mathrm{~h}^{-1}$ at Bowl A under aerobic conditions to rates of about $0.13 \mathrm{nmol} \mathrm{C}_{2} \mathrm{H}_{4}$ (g dry sed.) $)^{-1} \mathrm{~h}^{-1}$ at Hop A under anaerobic conditions (Table 4).

\section{Areal estimates}

In order to compare rates of activity and pool sizes within and among sites, values were converted to $\mathrm{a} \mathrm{m}^{-2}$ basis, integrated either over the top $2 \mathrm{~cm}$, or from 0 to $8 \mathrm{~cm}$ (Tables $6 \& 7$ ). Ammonium efflux was computed from the concentration gradient over the top few $\mathrm{cm}$ according to Fick's First Law, and using a diffusion coefficient adjusted for porosity and tortuosity, but not adsorption. For ammonification, intact core, depth profile data were used (Fig. 3). Similarly, depth profiles of $\mathrm{N}_{2}$ fixation (Fig. 4) and denitrification determined in minimally disturbed sediments were used. A 3:1 ratio of $\mathrm{C}_{2} \mathrm{H}_{2}$ reduced to $\mathrm{N}_{2}$ fixed was assumed. Ammonium utilization and $\mathrm{NO}_{3}{ }^{-}$reduction in the upper $2 \mathrm{~cm}$ were

Table 7 Areals rates of denitrification, nitrate reduction ammonium consumption, integrated to $2 \mathrm{~cm}$, and ammonium efflux in reef sediments. Units: $\mu \mathrm{mol} \mathrm{N} \mathrm{m}^{-2} \mathrm{~h}^{-1}$

\begin{tabular}{|c|c|c|c|c|}
\hline Site & Denitrif. ${ }^{a}$ & $\begin{array}{l}\mathrm{NO}_{3}{ }^{-} \\
\text {reduction }\end{array}$ & $\begin{array}{c}\mathrm{NH}_{4}{ }^{+} \\
\text {util. }^{c}\end{array}$ & $\begin{array}{l}\mathrm{NH}_{4}{ }^{+} \\
\text {efflux }\end{array}$ \\
\hline Pandora & $n d^{d}$ & nd & nd & 3.9 \\
\hline Hop 1 & nd & 36 & 58 & 2.2 \\
\hline Hop A & $0.12^{\mathrm{e}}$ & 37 & 45 & 1.7 \\
\hline Hop B & $0.18^{e}$ & 78 & 12.5 & 0.44 \\
\hline Hop C & $0.32^{e}$ & 9.4 & 48 & 1.1 \\
\hline Hop D & $0.45^{\mathrm{f}}$ & 33 & 43 & 0.66 \\
\hline Bowl A & $1.8^{\mathrm{f}}$ & 36 & 47 & 2.5 \\
\hline Bowl B & $0.20^{e}$ & 9.3 & 11 & nd \\
\hline Bowl C & $13.3^{f}$ & nd & nd & 0 \\
\hline \multicolumn{5}{|c|}{$\begin{array}{l}\text { "Denitrification, extrapolated to } 2 \mathrm{~cm} \text { sediment depth from } \\
\text { results of Table } 4 \text {, assuming no difference in rates over } \\
\text { the upper } 4 \mathrm{~cm} \text {, and a bulk sediment density of } 1 \mathrm{~g} \mathrm{~cm}^{-3} \\
\text { bxtrapolated to } 2 \mathrm{~cm} \text { sediment depth from } \mathrm{NO}_{3}^{-} \text {reduc- } \\
\text { tion data of aerobic slurries as presented in } \mathrm{Table} 4 \text { using }^{\text {the same assumptions as for denitrification }} \\
{ }^{\mathrm{C}} \mathrm{As} \text { for denitrification and } \mathrm{NO}_{2}^{-} \text {reduction, using the } \\
\mathrm{NH}_{4}^{+} \text {utilization estimates from aerobic slurries } \\
\mathrm{Not}^{-} \text {determined } \\
\text { Aerobic assay results } \\
\text { Anaerobic assay results }\end{array}$} \\
\hline
\end{tabular}


based on the $\mathrm{NH}_{4}{ }^{+}$and $\mathrm{NO}_{3}{ }^{-}$utilization potentials observed in aerobic slurry assays (Table 4). Graphical summaries of pools and fluxes for the 4 stations with the most complete information are presented in Figs. 5 through 8 .

At Pandora Reef, PON pools greatly exceeded $\mathrm{NH}_{4}{ }^{+}$ pools in the upper $2 \mathrm{~cm}$, but were similar when integrated over $8 \mathrm{~cm}$ depth (Fig. 5). The calculated $\mathrm{NH}_{4}{ }^{+}$ efflux was $3.9 \mu \mathrm{mol} \mathrm{N} \mathrm{m} \mathrm{N}^{-2} \mathrm{~h}^{-1}$ (Table 7). Ammonification rates were $6.6 \mu \mathrm{mol} \mathrm{N} \mathrm{m}{ }^{-2} \mathrm{~h}^{-1}$ for the upper $2 \mathrm{~cm}$ and $33 \mu \mathrm{mol} \mathrm{N} \mathrm{m} \mathrm{N}^{-2} \mathrm{~h}^{-1}$ for 0 to $8 \mathrm{~cm}$. Rates of $\mathrm{N}_{2}$ fixation were $55 \%$ of the $\mathrm{NH}_{4}{ }^{+}$production rate and $92 \%$ of the efflux estimate in the upper $2 \mathrm{~cm}$, and accounted for $16 \%$ of ammonification over the entire $8 \mathrm{~cm}$ depth interval.

At Hop A, PON increased from about $1200 \mu \mathrm{mol} \mathrm{N}$ $\mathrm{m}^{-2}$ in the upper $2 \mathrm{~cm}$ to about $4400 \mu \mathrm{mol} \mathrm{N} \mathrm{m} \mathrm{N}^{-2}$ over 0 to $8 \mathrm{~cm}$, while $\mathrm{NH}_{4}{ }^{+}$increased from $115 \mu \mathrm{mol} \mathrm{N} \mathrm{m}{ }^{-2}$ to $942 \mu \mathrm{mol} \mathrm{N} \mathrm{m}{ }^{-2}$ over the same interval (Fig. 6). The diffusion-driven $\mathrm{NH}_{4}{ }^{+}$flux rate was computed to be $1.7 \mu \mathrm{mol} \mathrm{N} \mathrm{m}{ }^{-2} \mathrm{~h}^{-1}$ (Table 7). While surficial ( 0 to $2 \mathrm{~cm}$ ) ammonification rates were comparable to Pandora Reef, rates over the entire depth interval were somewhat higher (Table 6). $\mathrm{N}_{2}$ fixation could account for $82 \%$ of the $\mathrm{NH}_{4}{ }^{+}$production in the upper $2 \mathrm{~cm}$, and about $19 \%$ of the $\mathrm{NH}_{4}{ }^{+}$production over the upper $8 \mathrm{~cm}$
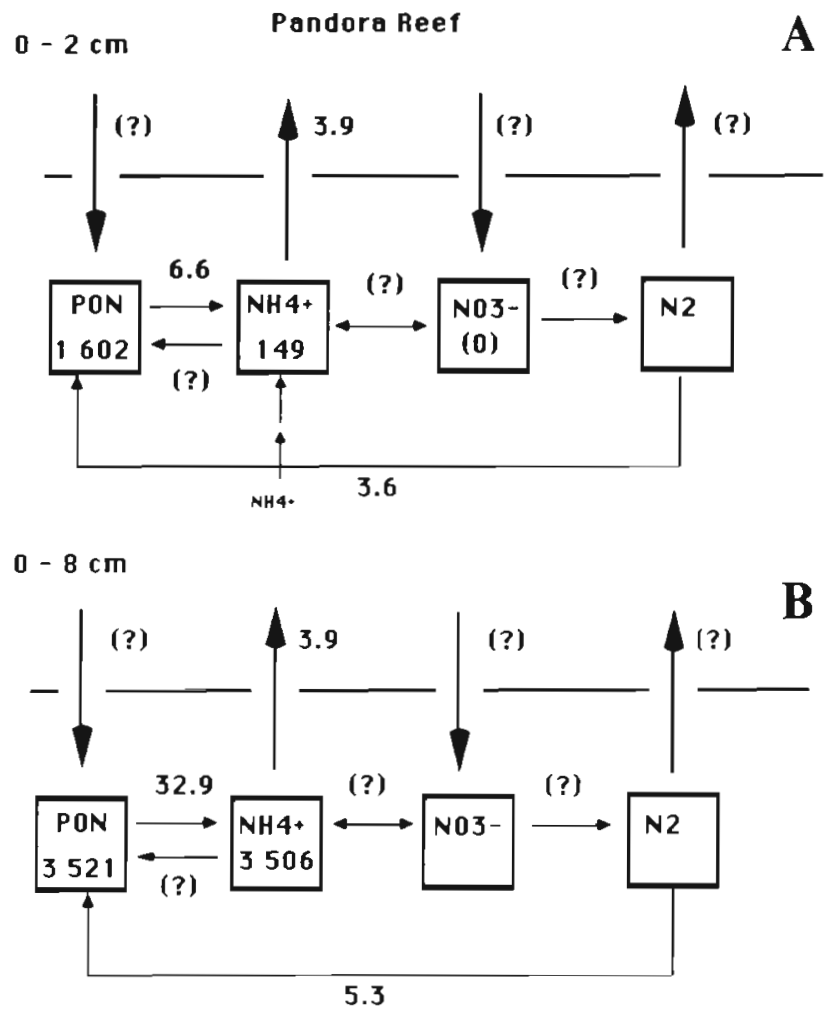

Fig. 5. Summary of pool sizes ( $\mu \mathrm{mol} \mathrm{N} \mathrm{m}^{-2}$ ) and transformations ( $\mu \mathrm{mol} \mathrm{m} \mathrm{m}^{-2} \mathrm{~h}^{-1}$ ) of nitrogen in the (A) $0-2 \mathrm{~cm}$ and $(\mathrm{B}) 0-8$ cm sediment horizons of Pandora Reef

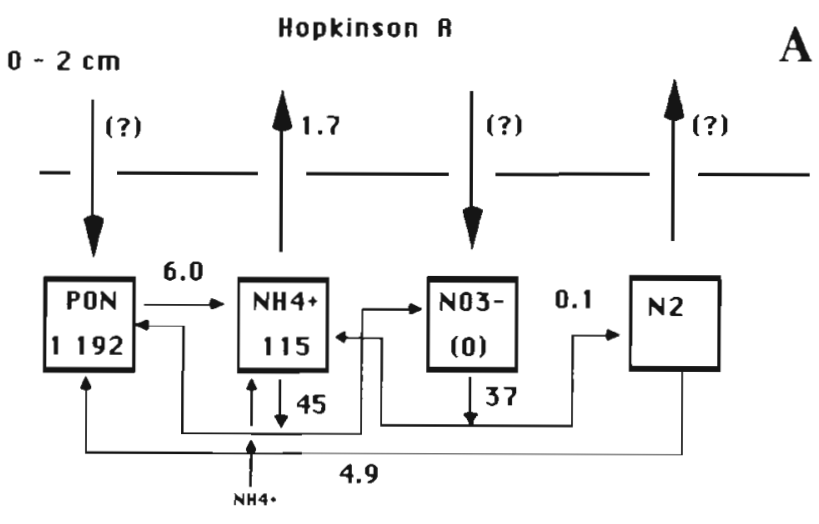

$0-8 \mathrm{~cm}$

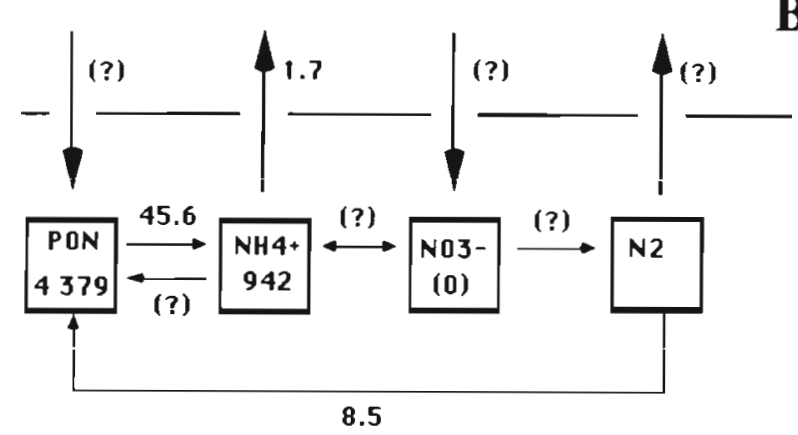

Fig. 6. Summary of pool sizes ( $\mathrm{umol} \mathrm{N} \mathrm{m}^{-2}$ ) and transformations $\left(\mu \mathrm{mol} \mathrm{m} \mathrm{m}^{-2} \mathrm{~h}^{-1}\right.$ ) of nitrogen in sediments of Hopkinson Reef, Site A, as for Fig. 5

(Table 6). In the upper $2 \mathrm{~cm}, \mathrm{NH}_{4}{ }^{+}$utilization potential in slurries was about 7.5 fold greater than $\mathrm{NH}_{4}{ }^{+}$production (Table 7). Nitrate reduction potential in these same assays was about $82 \%$ of the $\mathrm{NH}_{4}{ }^{+}$removal rate. Only a small fraction of the $\mathrm{NO}_{3}^{-}$reduction appeared to be denitrified.

At Hop C, PON pools increased from $976 \mu \mathrm{mol} \mathrm{N} \mathrm{m}{ }^{-2}$ in the upper $2 \mathrm{~cm}$ to about $3500 \mu \mathrm{mol} \mathrm{N} \mathrm{m}{ }^{-2}$ over the $8 \mathrm{~cm}$ interval, while $\mathrm{NH}_{4}{ }^{+}$increased from $74 \mu \mathrm{mol} \mathrm{N}$ $\mathrm{m}^{-2}$ to $680 \mu \mathrm{mol} \mathrm{N} \mathrm{m}{ }^{-2}$ (Fig. 7). Ammonium efflux was estimated to be $1.1 \mu \mathrm{mol} \mathrm{N} \mathrm{m} \mathrm{N}^{-2} \mathrm{~h}^{-1}$. Ammonification rates increased from $11.4 \mu \mathrm{mol} \mathrm{N} \mathrm{m}{ }^{-2} \mathrm{~h}^{-1}$ at the surface to $25.2 \mu \mathrm{mol} \mathrm{N} \mathrm{m} \mathrm{N}^{-2} \mathrm{~h}^{-1}$ over the top $8 \mathrm{~cm}$. As for Pandora and Hop A, $\mathrm{N}_{2}$ fixation could account for $72 \%$ of the $\mathrm{NH}_{4}{ }^{+}$production in the surface sediments, and $51 \%$ of $\mathrm{NH}_{4}{ }^{+}$production over the top $8 \mathrm{~cm}$ (Table 6). In the upper $2 \mathrm{~cm}$, the potential for $\mathrm{NH}_{4}{ }^{+}$utilization was also quite high and similar to Hop A (Table 7). Nitrate reduction potential was only about $20 \%$ of the $\mathrm{NH}_{4}{ }^{+}$ consumption rate, and denitrification could account for $3.4 \%$ of $\mathrm{NO}_{3}{ }^{-}$reduction.

Highest surface $\mathrm{NH}_{4}{ }^{+}$production rates were found at Bowl $A$ and this activity was essentially confined to the upper $2 \mathrm{~cm}$ (Figs. $3 \& 8$, Table 6). Ammonium efflux was estimated to be $2.5 \mathrm{umol} \mathrm{m}^{-2} \mathrm{~h}^{-1}$. In contrast to the other sites, $\mathrm{N}_{2}$ fixation only accounted for about $6 \%$ of the 
$\mathrm{NH}_{4}{ }^{+}$production in the upper $2 \mathrm{~cm}$, but $20 \%$ when integrated over the upper $8 \mathrm{~cm}$. Ammonium and $\mathrm{NO}_{3}{ }^{-}$ utilization potential and denitrification rates in the upper $2 \mathrm{~cm}$ at Bowl A were very similar to Hop A (Table 7).

\section{DISCUSSION}

While shallow carbonate sediments around coral reefs are often characterized as relatively poor in their content of organic and inorganic nutrients, particularly when compared to shallow temperate zone sediments, they nonetheless appear to be sites of active $N$ transformations. Previous studies have found $\mathrm{NH}_{4}{ }^{+}$production, $\mathrm{N}_{2}$ fixation, nitrification, $\mathrm{NO}_{3}{ }^{-}$reduction and denitrification to occur in various strata of these sediments (D'Elia \& Wiebe 1990). However, in the absence of concurrent assessment of each process along with $\mathrm{N}$ pools, it has been difficult to evaluate the relative importance of each process. Inherent methodological limitations of some of the procedures employed (see below), including the use of inhibitors and assays of potential rates, preclude a definitive assessment of the sedimentary $N$ cycle of these systems at present. Nonetheless, within the limits of the methods used, we
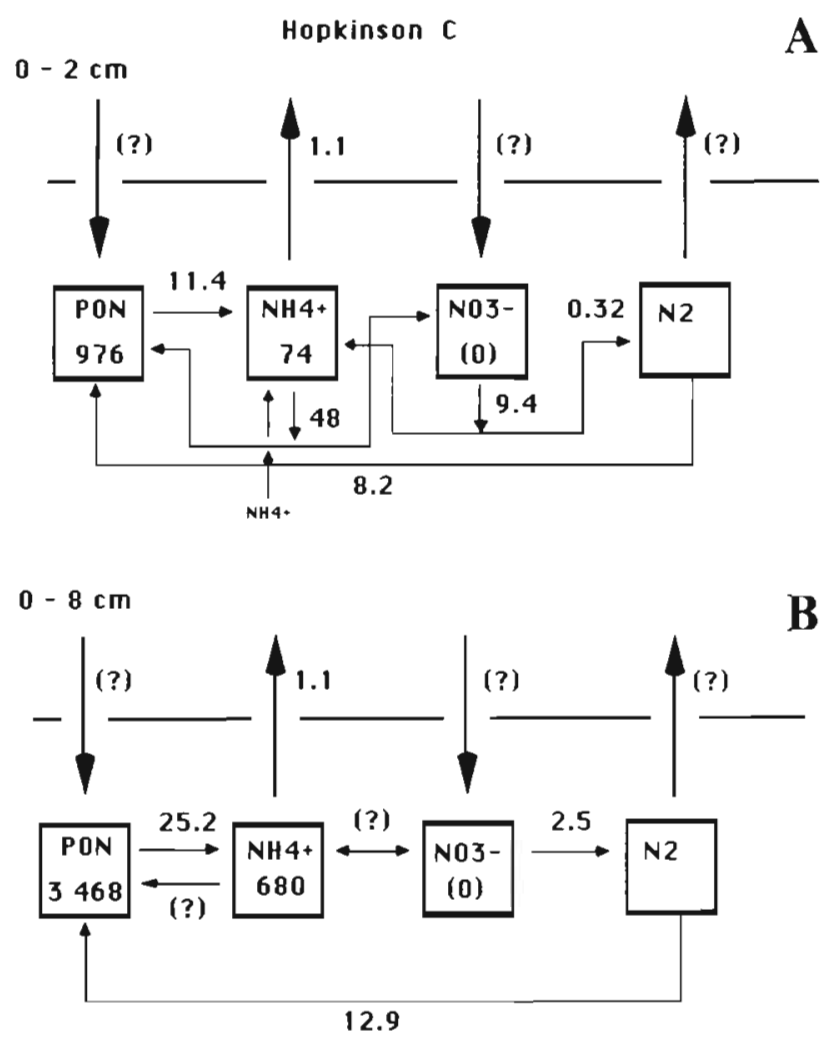

Fig. 7. Summary of pool sizes $\left(\mu \mathrm{mol} \mathrm{N} \mathrm{m}^{-2}\right)$ and transformations $\left(\mu \mathrm{mol} \mathrm{m}{ }^{-2} \mathrm{~h}^{-1}\right)$ of nitrogen in sediments of Hopkinson Reef, Site C, as for Fig. 5
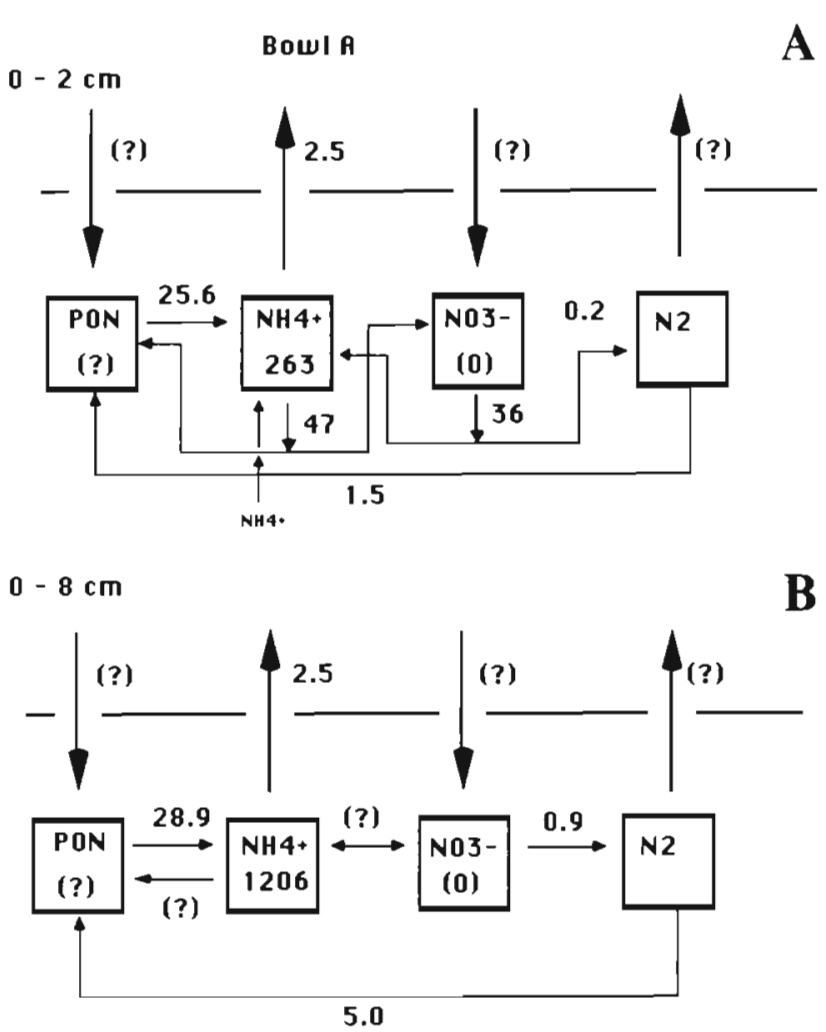

Fig. 8. Summary of pool sizes ( $\mu$ mol $\mathrm{N} \mathrm{m}^{-2}$ ) and transformations ( $\mu \mathrm{mol} \mathrm{m} \mathrm{m}^{-2} \mathrm{~h}^{-1}$ ) of nitrogen in sediments of Bowl Reef, Site A, as for Fig. 5

can now provide a more comprehensive understanding of several important $\mathrm{N}$ species and transformations.

\section{Ammonium concentrations and fluxes}

Relative to temperate zone areas, there is sparse information on pore water nutrients of reef environments, possibly because of the difficulty in obtaining samples from consolidated substrata (D'Elia \& Wiebe 1990). Several of the available studies are summarized in Table 8.

We found $\mathrm{NH}_{4}{ }^{+}$concentrations to vary substantially among sediment types. Relatively low $\mathrm{NH}_{4}{ }^{+}$concentrations were noted in coarse- and medium-grained carbonate sediments, usually less than $10 \mu \mathrm{M}$ at $10 \mathrm{~cm}$ depth (Fig. 2). Fine-grained sediments had steeper $\mathrm{NH}_{4}{ }^{+}$gradients, reaching 15 to $30 \mu \mathrm{M}$ by $8 \mathrm{~cm}$. Highest $\mathrm{NH}_{4}{ }^{+}$concentrations (Table 1 ) and inventories (Figs. 5 to 8 ) in our study were found in muddy sediments, reaching up to $60 \mu \mathrm{M}$ at $8 \mathrm{~cm}$ depth.

Several previous studies have estimated $\mathrm{NH}_{4}{ }^{+}$fluxes in tropical carbonate sediments based on pore water profiles or by use of benthic chambers (Table 9). Two studies reported relatively poor agreement between 
Table 8. Reported maxima in ammonium concentrations in tropical carbonate sediments

\begin{tabular}{|lll|}
\hline $\mathrm{NH}_{4}{ }^{+}$concentration $(\mu \mathrm{M})$ & \multicolumn{1}{c}{ Comment } & Source \\
\hline $40-300$ & Cores, centrifuge, by $14 \mathrm{~cm}$; various sites nearshore Bermuda & Hines et al. (1982) \\
$2.3-16.3$ & Sipper, upper $10 \mathrm{~cm}$; Davies Reef, Great Barrier Reef & Entsch et al. (1983) \\
$9.6-64$ & Extract, upper $10 \mathrm{~cm}$, same site & Entsch et al. (1983) \\
$20-40$ & Sipper, by $15 \mathrm{~cm}$; fringing reefs, SW Puerto Rico & Corredor \& Morrell (1985) \\
$15-30$ & Core, by $8 \mathrm{~cm}$, sands & This study \\
60 & Core, by $8 \mathrm{~cm}$, muds & This study \\
\hline
\end{tabular}

Table 9. Reported rates of nitrogen transformations

\begin{tabular}{|c|c|c|}
\hline $\begin{array}{l}\text { Transformation rate } \\
\left(\mu \mathrm{mol} \mathrm{m} \mathrm{m}^{-2} \mathrm{~h}^{-1}\right)\end{array}$ & Comment & Source \\
\hline \multicolumn{3}{|l|}{$\mathrm{NH}_{4}{ }^{+}$efflux } \\
\hline $0.7-0.96$ & Modeled, diffusive; fringing reefs, SW Puerto Rico, Mona Is. & Corredor \& Morrell (1985) \\
\hline $0-0.8$ & Modeled, diffusive; Tikehau Lagoon, French Polynesia & Charpy et al. (unpubl.) \\
\hline $50-704$ & Anoxic, chamber; same site & Charpy et al. (unpubl.) \\
\hline 0.39 & Modeled, diffusive; Hydrolab., St. Croix & Fisher et al. (1990) \\
\hline 35 & Dark chamber; same site & Fisher et al. (1990) \\
\hline 3.0 & Chambers; backreef, Tague Bay, St. Croix & Williams et al. (1985) \\
\hline $0.4-4.0$ & Modeled, diffusive & This study \\
\hline \multicolumn{3}{|l|}{ Ammonification } \\
\hline 4.5 & Direct, tube pack; same site & Williams et al. (1985) \\
\hline $5-300$ & Modeled from $\mathrm{SO}_{4}{ }^{+}$red.; same sites & Hines et al. (1982) \\
\hline $4.4-28$ & In core, $0-2 \mathrm{~cm}$ & This study \\
\hline $9.8-50$ & In core, $0-8 \mathrm{~cm}$ & This study \\
\hline \multicolumn{3}{|l|}{ Deposition } \\
\hline $125-618$ & Sediment traps; same sites & Fisher et al. (1990) \\
\hline 109 & Sedient traps; Tuamotu lagoon, French Polynesia & Charpy \& Charpy-Robaud (1991) \\
\hline 357 & Sediment traps, One Tree Is., Great Barrier Reef & Koop \& Larkum (1987) \\
\hline \multicolumn{3}{|l|}{ Denitrification } \\
\hline 19 & $\mathrm{C}_{2} \mathrm{H}_{2}$ blockage; lagoonal seds., Bahamas & Seitzinger \& D'Elia (1985) \\
\hline $50-100$ & $\mathrm{C}_{2} \mathrm{H}_{2}$ blockage; fringing reefs, SW Puerto Rico \& Mona Is. & Corredor \& Capone (1985) \\
\hline $0.12-13$ & & This study \\
\hline \multicolumn{3}{|l|}{$\mathrm{N}_{2}$ fixation } \\
\hline 2.7 & $\mathrm{C}_{2} \mathrm{H}_{2}$ red. ${ }^{a} ;{ }^{15} \mathrm{~N}_{2} ;$ Barbados & Patriquin \& Knowles (1972) \\
\hline 5.1 & $\mathrm{C}_{2} \mathrm{H}_{2}$ red.; Kanehoe Bay, Hawaii & Hanson \& Gunderson (1976) \\
\hline $1.7-12.7$ & $\mathrm{C}_{2} \mathrm{H}_{2}$ red.; Great Barrier Reef & Wilkinson et al. (1984) \\
\hline $6.5-12.8$ & $\mathrm{C}_{2} \mathrm{H}_{2}$ red.; muds, same sites & Corredor \& Capone (1985) \\
\hline $0.4-3.6$ & $\mathrm{C}_{2} \mathrm{H}_{2}$ red.; sands, same sites & Corredor \& Capone (1985) \\
\hline $3-12$ & $\mathrm{C}_{2} \mathrm{H}_{2}$ red.; muds, Bermuda & O'Neil \& Capone (1989) \\
\hline $0.4-11.5$ & $\mathrm{C}_{2} \mathrm{H}_{2}$ red; sands, Bermuda & O'Neil \& Capone (1989) \\
\hline 6 & $\mathrm{C}_{2} \mathrm{H}_{2}$ red.; Hydrolab., St. Crolx & King et al. (1990) \\
\hline $4-10$ & $\mathrm{C}_{2} \mathrm{H}_{2}$ red.; ${ }^{15} \mathrm{~N}_{2} ;$ Australia & O'Donohue et al. (1991) \\
\hline $5-13$ & $\mathrm{C}_{2} \mathrm{H}_{2}$ red. & This study \\
\hline
\end{tabular}

modeled and empirically determined fluxes using benthic chambers. Charpy-Roubaud et al. (unpubl.) found $\mathrm{NH}_{4}{ }^{+}$release in benthic chambers was often several-fold higher than modeled fluxes, particularly in chambers with artificially lowered $\mathrm{O}_{2}$ concentrations. Similarly, modeled fluxes reported by Fisher et al. (1990) were about $0.4 \mu \mathrm{mol} \mathrm{m}^{-2} \mathrm{~h}^{-1}$ compared to directly measured averaged rates of about $35 \mu \mathrm{mol} \mathrm{m}{ }^{-2}$ $\mathrm{h}^{-1}$ using benthic flux chambers (Table 9). In Fisher et al., rates varied greatly over the diel cycle, with net $\mathrm{NH}_{4}{ }^{+}$influxes during the day which were attributed to photoautotrophic activity. Williams et al. (1985) reported $\mathrm{NH}_{4}{ }^{+}$efflux rates in backreef sediments averaging $3 \mu \mathrm{mol} \mathrm{m}{ }^{-2} \mathrm{~h}^{-1}$; these rates compared favorably to 
depth-integrated ammonification of $4.5 \mu \mathrm{mol} \mathrm{m} \mathrm{m}^{-2} \mathrm{~h}^{-1}$. They noted rapid turnover of $\mathrm{NH}_{4}{ }^{+}$pools, with average residence times of $2.2 \mathrm{~h}$. Hines et al. (1982) predicted ammonium production rates from measured sulfate reduction for the top $14 \mathrm{~cm}$ of organically enriched carbonate sediments of Bermuda (Table 9) with residence times of 0.4 to $25 \mathrm{~d}$.

Our estimates of $\mathrm{NH}_{4}{ }^{+}$efflux, based strictly on the diffusion driven flux, ranged from 0.4 to $3.9 \mu \mathrm{mol} \mathrm{m} \mathrm{m}^{-2}$ $\mathrm{h}^{-1}$ (Table 7 ). Ammonification rates in the upper $2 \mathrm{~cm}$ ranged from 6 to $26 \mu \mathrm{mol} \mathrm{m} \mathrm{m}^{-2} \mathrm{~h}^{-1}$, and from 12 to 46 $\mu \mathrm{mol} \mathrm{m} \mathrm{m}^{-2} \mathrm{~h}^{-1}$ for the upper $8 \mathrm{~cm}$. Except for Pandora Reef, where $\mathrm{NH}_{4}{ }^{+}$efflux could account for $59 \%$ of surficial ammonification, $\mathrm{NH}_{4}{ }^{+}$efflux was less than $30 \%$ of ammonification. Ammonium turnover in the upper $2 \mathrm{~cm}$ was rapid, ranging from 0.04 to $0.15 \mathrm{~h}^{-1}$ (6.6 to $25 \mathrm{~h}$ ) (Table 6).

Surficial sediments at most sites incubated aerobically in the dark also exhibited very high potentials for $\mathrm{NH}_{4}{ }^{+}$consumption (Table 7). At Hop $\mathrm{C}$, in shallow water just behind the reef crest, parallel rapid production of $\mathrm{NO}_{3}{ }^{-}$indicated that nitrification could explain a large fraction of this flux. We confirmed this with ${ }^{15} \mathrm{~N}$ and inhibitor studies (Table 5). Our areal rates are comparable to the observations of Webb \& Wiebe (1975) detailing high nitrification rates associated with the reef flat. At most of the deeper sites, however, $\mathrm{NO}_{3}{ }^{-}$ was consumed rather than produced, making it less obvious that nitrification was a primary fate for $\mathrm{NH}_{4}{ }^{+}$. Ammonium removal may also be associated with autotrophic or heterotrophic uptake. Sumi \& Koike (1990), using a ${ }^{15} \mathrm{~N}$ procedure, have recently reported that in surficial sediments, microbial assimilation of $\mathrm{NH}_{4}{ }^{+}$can at times exceed ammonification. Rapid $\mathrm{NO}_{3}{ }^{-}$removal, as observed at most deeper sites, may also be attributed to assimilatory $\mathrm{NO}_{3}{ }^{-}$reduction (D'Elia \& Wiebe 1990). However, denitrification occurred under apparently aerobic conditions (Table 4) and may also contribute to apparent $\mathrm{NO}_{3}{ }^{-}$removal (see below).

\section{$\mathrm{N}_{2}$ fixation}

Several recent studies have observed nitrogenase activity in non-vegetated, shallow carbonate sediments from a diverse range of environments (O'Neil \& Capone 1989, King et al. 1990, O'Donohue et al. 1991) (Table 9). Nitrogenase activities reported in these studies, ranging from 0.4 to $12 \mu \mathrm{mol} \mathrm{m} \mathrm{m}^{-2} \mathrm{~h}^{-1}$, were very similar to our present results, which ranged from 5 to $13 \mu \mathrm{mol} \mathrm{m} \mathrm{m}^{-2} \mathrm{~h}^{-1}$. Several of these authors $1 \mathrm{O}^{\prime}$ Neil \& Capone 1989, King et al. 1990) speculated that $N_{2}$ fixation might be more important in the $\mathrm{N}$ cycle of these environments, compared to more $\mathrm{N}$ rich temperate sediments. However, the supporting data $\left(\mathrm{NH}_{4}{ }^{+}\right.$dis- tributions, inventories and production rates) to assess the relative importance of $\mathrm{N}_{2}$ fixation to the nitrogen cycle were lacking. In the present study, we have directly compared $\mathrm{N}_{2}$ fixation to concurrent rates of $\mathrm{NH}_{4}{ }^{+}$production and found that, at 3 out of 4 sites, $\mathrm{N}_{2}$ fixation in surficial sediments $(0$ to $2 \mathrm{~cm}$ ) could account for greater than $50 \%$ of the $\mathrm{NH}_{4}{ }^{+}$production (Table 6 ). This is in sharp contrast to unvegetated shallow sediments in temperate zones where $\mathrm{N}_{2}$ fixation may only account for a very small fraction of the nitrogen input to and turnover within the sediment (e.g. Nixon \& Pilson 1983).

Some concern has been expressed about the validity of $\mathrm{C}_{2} \mathrm{H}_{2}$ reduction-based estimates of $\mathrm{N}_{2}$ fixation in marine sediments (Capone 1988). One concern has been the supposition that $\mathrm{N}_{2}$ fixation should be inhibited at the very high ambient $\mathrm{NH}_{4}{ }^{+}$concentrations often found in shallow temperate zone sediments (Capone 1988). While the sensitive $\mathrm{C}_{2} \mathrm{H}_{2}$ reduction assay can detect nitrogenase activity in such systems, it has also been shown that $\mathrm{C}_{2} \mathrm{H}_{2}$ reducing activity can be far below potential levels and may indeed be inhibited (Capone 1988). With respect to the carbonate sediments examined herein, nitrogenase activity was maximal near the surface (Fig. 4) where $\mathrm{NH}_{4}{ }^{+}$concentrations were often the lowest and generally less than $10 \mu \mathrm{M}$ (Fig. 2, Table 1). This is well below concentrations known to inhibit nitrogenase synthesis or activity (e.g. Neilson \& Nordlund 1975, Zumft \& Castillo 1978, Kleinschmidt \& Kleiner 1981). Thus, it is not surprising that $\mathrm{N}_{2}$ fixation may be a more quantitatively important process in these systems.

With regard to converting $\mathrm{C}_{2} \mathrm{H}_{2}$ reduction to $\mathrm{N}_{2}$ fixation, Patriquin \& Knowles (1972) and more recently O'Donohue et al. (1991) directly compared $\mathrm{C}_{2} \mathrm{H}_{2}$ reduction with direct ${ }^{15} \mathrm{~N}_{2}$ fixation in vegetated and nonvegetated carbonate sediments and found empirically derived ratios very close to the theoretical 3 to 1 value.

\section{Denitrification}

Denitrification has been reported in 2 previous studies of coral reef sediments. Seitzinger \& D'Elia (1985), using the $\mathrm{C}_{2} \mathrm{H}_{2}$ blockage procedure, estimated denitrification rates of $19 \mu \mathrm{mol} \mathrm{N} \mathrm{m}^{-2} \mathrm{~h}^{-1}$ (integrated to $5 \mathrm{~cm}$ ) (Table 9). Corredor \& Capone (1985), using the same method, found denitrification ranging from 50 to $100 \mu \mathrm{mol} \mathrm{m} \mathrm{m}^{-2} \mathrm{~h}^{-1}$.

In general, our areal estimates presented here, restricted to $2 \mathrm{~cm}$ depth (Table 7 ), are on the low range of these previous estimates. We only performed limited studies on the depth distribution of denitrification. As mentioned, at 1 site (Bowl A), denitrification rates were relatively similar at each horizon down to $8 \mathrm{~cm}$ and 
integration to greater depth would probably bring our estimates closer to these earlier observations.

However, there are potential limitations with the present (and previous) denitrification estimates. For one, the $\mathrm{C}_{2} \mathrm{H}_{2}$ block of $\mathrm{N}_{2} \mathrm{O}$ reductase becomes ineffective at ambient levels of $\mathrm{NO}_{3}^{-}$below 5 to $10 \mu \mathrm{M}$ (see Slater \& Capone 1989 and references therein). Also, limitation of denitrification by nitrification appears to occur in temperate sediments (Jenkins \& Kemp 1984, Horrigan \& Capone 1985) and has been suggested as an important controlling factor for denitrification in tropical sediments (Corredor \& Capone 1985). Further confounding the quantitative estimation of denitrification rates by $\mathrm{C}_{2} \mathrm{H}_{2}$ blockage in low $\mathrm{NO}_{3}{ }^{-}$environments is the fact that nitrification, and hence $\mathrm{NO}_{3}{ }^{-}$production, is also inhibited by $\mathrm{C}_{2} \mathrm{H}_{2}$ (Payne 1984).

Sediment $\mathrm{NO}_{3}{ }^{-}$was generally undetectable and therefore well below $5 \mu \mathrm{M}$. Additions of $\mathrm{NO}_{3}{ }^{-}$over the range $10 \mu \mathrm{M}$ to $500 \mu \mathrm{M}$ produced an immediate, concentration-dependent stimulation of denitrification (Capone unpubl.) indicating a very high potential for denitrification. Thus, the present estimates should be considered as mintind, pal iiculaly in liyili of high tates of $\mathrm{NO}_{3}{ }^{-}$production and removal as suggested by nitrification assays and potential $\mathrm{NH}_{4}{ }^{+}$and $\mathrm{NO}_{3}{ }^{-}$utilization.

One interesting aspect of the denitrification data is that assays conducted under aerobic conditions often resulted in rates similar to and, at times, greater than those conducted in parallel under anoxic conditions (Table 4). A particularly noteworthy case was for samples obtained from the very shallow reef flat near the reef face at Hop C. This site is often exposed to high wave action and turbulence and the coarse-grained sands and high flow would suggest relatively wellaerated conditions near the sediment water interface. (No sediment $\mathrm{O}_{2}$ data was collected in our study.) While denitrification is traditionally viewed as an anaerobic process with the induction of the denitrifying enzymes often dependent upon low $\mathrm{O}_{2}$ (Payne 1981), organisms with a capacity for aerobic denitrification are known (Robertson \& Kuenen 1984) and aerobic denitrification has been suggested in some natural environments (Dodds \& Jones 1987). Aiternatively, the coarse skeletal particles which comprise these sands may allow the development of anoxic microzones as has been previously shown by Patriquin \& Knowles (1975).

\section{Deposition and fate of particulate nitrogen}

While we did not directly determine particulate $\mathrm{N}$ (PN) sedimentation rates in our study, several investigations have provided data on the rate of $\mathrm{PN}$ input to shallow carbonate environments (Table 9). Recent estimates range from about 100 to $600 \mu \mathrm{mol} \mathrm{N} \mathrm{m}^{-2} \mathrm{~h}^{-1}$ (Table 9). If PN sedimentation was similar at our sites, only a small portion of such input can be accounted for by $\mathrm{NH}_{4}{ }^{+}$efflux. Our downcore PN analysis (Table 3) indicated preservation of well over half the surficial PN in the 6 to $8 \mathrm{~cm}$ horizon. Nonetheless, other fates for deposited nitrogen are indicated and need to be quantified. In this regard, the observations of both Fisher et al. (1990) and Charpy-Roubaud et al. (unpubl.) that chamber-derived fluxes can greatly exceed diffusively modeled estimates deserve further examination. Similarly, underestimation of denitrification could account for further, unaccounted losses.

\section{Conclusions}

The $\mathrm{NH}_{4}{ }^{+}$pool in the upper few $\mathrm{cm}$ of tropical carbonate sediments appears to be highly dynamic, with inferred internal turnover times of substantially less than a day. Nitrification appears to be a quantitatively impontani $N$-cycle conponent in shallow, teef nat areas. Denitrification can be detected, even in apparently oxic sediments, but its quantitative importance is unresolved. Our data indicate that bacterial $\mathrm{N}_{2}$ fixation accounts for a large fraction of the $\mathrm{NH}_{4}{ }^{+}$produced within or released from the upper layers of the sediments.

Acknowledgements. The authors thank the various staff members at AIMS for their generous and invaluable assistance during and after our visit. In particular, we thank our hosts Drs Bruce Chalker and Dave Barnes and their associates, Mr Alan Nott and Mr Frank Tirendi of the Analytical Services group and the Masters and crew of the RV 'Sirius' and RV 'Lady Basten' Help with sampling and subsequent valuable discussion with Dr William Dennison are greatly appreciated. The facilities of Dr Jim McCarthy of Harvard University were kindly provided for the ${ }^{15} \mathrm{~N}$ analyses. Dr Don Rice lent his expertise on the flux modeling. We also thank Ms Judy O'Neil for postcruise support and discussion. This research was conducted with support from National Science Foundation grants from the US/Australia Cooperative Research Program (INT 83-17 747), and the Division of Ocean Sciences (OCE 84$17595,85-42088$ )

\section{LITERATURE CITED}

Belser, L W., Mays, E. L. (1982). Use of nitrifier activity measurements to estimate the efficiency of viable nitrifier counts in soils and sediments. Appl. environ. Microbiol. 43: 945-948

Berner, R. A. (1980). Early diagenesis: a theoretical approach Princeton University Press, Princeton, NJ

Capone, D. G. (1982). Nitrogen fixation (acetylene-reduction) by rhizosphere sediments of the eelgrass, Zostera marina L. Mar Ecol. Prog. Ser. 10: 67-75

Capone, D. G. (1983). Benthic nitrogen fixation. In: Carpenter, 
E. J., Capone, D. G. (eds.) Nitrogen in the marine environment. Academic Press, New York, p. 105-137

Capone, D. G. (1988). Benthic nitrogen fixation: microbiology, physiology and ecology. In: Blackburn, T H., Sorensen, J. (eds.) Nitrogen cycling in marine coastal environments. SCOPE Series. J. Wiley \& Sons, New York, p. 85-123

Charpy, L., Charpy-Roubaud, J. (1991). Particulate organic matter fluxes in a Tuamotu atoll lagoon (French Polynesia). Mar Ecol. Prog. Ser. 71: 53-63

Corredor, J. E., Capone, D. G. (1985). Studies on nitrogen diagenesis in coral reef sands. In: Gabrie, C. et al. (eds.) Proc. 5th int coral Reef Congr. Antenne Museum - EPHE, Moorea, French Polynesia 3: 395-399

Corredor, J. E., Morell, J. (1985). Inorganic nitrogen in coral reef sediments. Mar. Chem. 16: 379-384

D'Elia, C. F. (1988). Concepts of ecosystem ecology: a comparative view. In: Pomeroy, L. R., Alberts, J. J. (eds.) Ecological studies 67 Springer Verlag, New York

D'Elia, C. F., Wiebe, W. J. (1990). Biogeochemical nutrient cycles in coral-reef ecosystems. In: Dubinsky, Z. (ed.) Coral reefs. Elsevier Science Publishers, Amsterdam, p. $49-74$

DiSalvo, L. H. (1973). Microbial ecology. In: Jones, O. A., Endean, R. (eds.) Biology and ecology of coral reefs, Vol. II. Academic Press, New York, p. 1-45

Dodds, W. K., Jones, R. D. (1987). Potential rates of nitrification and denitrification in an oligotrophic freshwater sediment system. Microb. Ecol. 14: 91-100

Entsch, B. K., Boto, G., Sim, R. G., Wellington, T J. (1983) Phosphorus and nitrogen in coral reef sediments. Limnol. Oceanogr. 28: $465-476$

Fisher, T R., Morrissey, K. M. Smith, L. K., Williams, S. L. Baptist, G., Ward, L. G., Twilley, R., D Elia, C. F., Zimba, P F. (1990). Final science report of NURP Hydrolab Mission 85-1 NOAA, Washington, D.C.

Hanson, R. B., Gunderson, K. R. (1976). Bacterial nitrogen fixation in a polluted coral reef flat ecosystem, Kanehoe Bay, Oahu, Hawaiian Islands. Pacif. Sci. 30: 385-393

Hardy, R. W. F., Holsten, R. D., Jackson, E. K., Burns, R. C (1968). The acetylene-ethylene assay for $\mathrm{N}_{2}$ fixation: laboratory and field evaluation. Plant Physiol. 43: 1185-1207

Hines, M. E., Lyons, W B. (1982). Biogeochemistry of nearshore Bermuda sediments. I. Sulfate reduction rates and nutrient regeneration. Mar. Ecol. Prog. Ser. 8: 87-94

Horrigan, S. G., Capone, D. G. (1985). Rates of nitrification and nitrate reduction in nearshore marine sediments under varying environmental conditions. Mar. Chem. 16: $317-327$

Jenkins, M. C., Kemp, W M. Jr (1984). The coupling of nitrification and denitrification in two estuarine sediments. Limnol. Oceanogr 29: 609-619

King, G. M., Carlton, R. G., Sawyer, T E. (1990). Anaerobic metabolism and oxygen distribution in the carbonate sediments of a submarine canyon. Mar Ecol. Prog. Ser. 58: $275-285$

Kleinschmidt, J. A., Kleiner, D. (1981). Relationship between nitrogenase, glutamine synthetase, glutamine and energy charge in Azotobacter vinelandii. Arch. Microbiol. 128: $412-415$

Koike, I., Hattori, A. (1978). Simultaneous determinations of nitrification and nitrate reduction in coastal sediments by a ${ }^{15} \mathrm{~N}$-dilution technique. Appl. environ. Microbiol. 35: 853-857

Koop, K., Larkum, A. W D. (1987). Deposition of organic material in a coral reef lagoon, One tree Island, Great Barrier Reef. Estuar coast. Shelf Sci. 25: 1-9
Krom, M., Berner, R. A. (1980). The diffusion coefficients of sulfate, ammonium and phosphate ions in anoxic marine sediments. Limnol. Oceanogr 25: 327-337

Li, Y H., Gregory, S. (1974). Diffusion of ions in seawater and in deep-sea sediments. Geochim. Cosmochim. Acta 38 703-714

Nedwell, D. B., Blackburn, T H. (1987). Anaerobic metabolism in lagoon sediments from Davies Reef, Great Barrier Reef Estuar coast. Shelf Sci. 25: 347-353

Neilson, A. H., Nordlund, S. (1975). Regulation of nitrogenase synthesis in intact cells of Rhodospirillum rubrum: inactivation of nitrogen fixation by ammonium, L-glutamine and L-asparagine. J. gen. Microbiol. 91. 53-62

Nixon, S. W., Pilson, M. (1983). Nitrogen in estuarine and coastal marine ecosystems. In: Carpenter, E. J., Capone, D $G$. (eds.) Nitrogen in the marine environment. Academic Press, New York, p. 565-648

ODonohue, M. J., Moriarty, D. J. W., MacRae, I. C. (1991). Nitrogen fixation in sediments and the rhizosphere of the seagrass Zostera capricorni. Microb. Ecol. 22: 53-64

O'Neil, J. M., Capone, D. G. (1989). Nitrogenase activity in tropical carbonate marine sediments. Mar. Ecol. Prog. Ser 56: $145-156$

Payne, W. J. (1981). Denitrification. John Wiley \& Sons, New York

Payne, W. J. (1984). Influence of acetylene on microbial and enzymatic assays. J. microbiol. Meth. 2: 117-133

Patriquin, D. G., Knowles, R. (1972). Nitrogen fixation in the rhizosphere of marine angiosperms. Mar. Biol. 32: $227-242$

Patriquin, D. G, Knowles, R. (1975). Effects of oxygen, mannitol and ammonium concentration on nitrogenase $\left(\mathrm{C}_{2} \mathrm{H}_{2}\right)$ activity in a marine skeletal carbonate sand. Mar. Biol. 32: $49-62$

Robertson, L. A., Kuenen, J. G. (1984). Aerobic denitrification: a controversy revived. Arch. Microbiol. 139: 351-354

Rosenfield, J. K. (1979). Ammonium adsorption in nearshore anoxic sediments. Limnol. Oceanogr 24:356-364

Sandstrom, M. W., Tirendi, F., Nott, A. (1986). Direct determination of organic carbon in modern reef sediments and calcareous organisms after dissolution of carbonates. Mar Geol. 70: 321-329

Seitzinger, S., D'Elia, C. (1985). Preliminary studies of denitrification on a coral reef. In: Reaka, M. L. (ed.) The ecology of coral reefs. NOAA Symp. Ser. Undersea Res., p. $199-208$

Slater, J. M., Capone, D. G. (1987). Denitrification in aquifer soils and nearshore marine sediments influenced by groundwater nitrate. Appl. environ. Microbiol. 53: 1292-1297

Slater, J., Capone, D. G. (1989). Nitrate requirement for acetylene inhibition of nitrous oxide reduction in marine sediments. Microb. Ecol. 26: 181-198

Smith, S. V (1984). Phosphorus versus nitrogen limitation in the marine environment. Limnol. Oceanogr. 29: 1149-1160

Stewart, W. P. D., Fitzgerald, G. P., Burris, R. H. (1967). In situ studies on $\mathrm{N}_{2}$ fixation using the acetylene reduction technique. Proc natn. Acad. Sci. U.S.A. 58: 2071-1078

Strickland, J. D. H., Parsons, T. R. (1972). A practical handbook of seawater analysis. Bull. Fish. Res. Bd Can. 167: $1-311$

Sumi, T., Koike, I. (1990). Estimation of ammonification and ammonium assimilation in surficial coastal and estuarine sediments. Limnol. Oceanogr. 35: 270-286

Webb, K. L., Wiebe, W. J. (1975). Nitrification on a coral reef. Can. J. Microbiol. 21: 1427-1431

Wilkinson, C. R., Williams, D. M., Sammarco, P. W., Hogg, R. 
W., Trott, L. A. (1984). Rates of nitrogen fixation rates on coral reefs across the continental shelf on the central Great Barrier Reef. Mar. Biol. 80: 255-262

Williams, S. L., Yarish, S. M., Gill, I. P. (1985). Ammonium distributions, production, and efflux from backreef sedi-

This manuscript was presented by K. R. Tenore, Solomons, Maryland, USA ments, St. Croix, US Virgin Islands. Mar. Ecol. Prog. Ser 24: $57-64$

Zumft, W G., Castillo, F. (1978). Regulatory properties of the nitrogenase from Rhodopseudomonas palustris. Arch. Microbiol. 117: 53-60

Manuscript first received: August 13, 1991

Revised version accepted: December 19, 1991 